\title{
An Overview of Composting Based on Variable Feedstock Material
}

\author{
Aeslina Abdul Kadir ${ }^{1, a}$, Siti Noratifah Jamaludin ${ }^{1}$ and Nur Wahidah Azhari ${ }^{1}$ \\ ${ }^{1}$ Faculty of Civil and Environmental Engineering, University Tun Hussein Onn Malaysia, 86400 Parit Raja, Johor, \\ Malaysia
}

\begin{abstract}
Composting is a biological treatment method that provides a potential sustainable way to convert food waste into organic compost. In composting, the feedstock material is an important item to ensure the success of the composting process. This paper reviewed the process of composting based on implementation different types of feedstock, namely: 1) animal waste such as cow dung, poultry litter, swine manure and chicken manure; and 2) agricultural waste such as sawdust, rice straw, bran, bagasse, banana waste and pine chip. The result for poultry litter, cow manure, swine manure, sawdust and rice straw has $\mathrm{C} / \mathrm{N}$ ratio lower than 20 at final composting process which is considered as satisfactory level for compost maturity. As a conclusion, the selection of the feedstock material is based on the characteristics of the material itself and the selection of materials is important for the quality of compost.
\end{abstract}

\section{Introduction}

In Malaysia, solid waste generation has increased more than $91 \%$ over the past 10 years, due to the rapid development of urban areas [1]. Currently, Malaysia produced approximately 30,000 metric tons of waste every day or $1.3 \mathrm{~kg} /$ person/day [2]. The waste consists of domestic and industrial refuse. Waste management due to rapid urbanisation has become a serious concern for government departments, pollution control agencies, regulatory bodies and also public.

Proper waste management is very important to prevent further environmental destruction and to promote sustainable development. Sustainable development aims to meet human needs while preserving the environment so that these needs can be met not only in the present, but also for future generations. The $3.6 \%$ annual increase in solid waste generation required appropriate facilities and technologies which are unfortunately not available to match the requirement for sustainable waste management [3]. Sanitary landfills are only $3 \%$ of the total existing disposal sites in the country while the remaining are non-sanitary landfills [4]. This makes the management of waste in Malaysia is more delicate matter to tackle and constrain to establish a sustainable waste management system. The characteristics of municipal solid waste (MSW) components also play important roles to determine the suitability of the disposal systems. Solid waste composition in most Asian countries is highly biodegradable with high moisture content such as food waste, paper, agriculture waste and textiles [5]. In Malaysia, the average components of MSW are quite similar with the largest categories consist of food waste $(43.5 \%)$, plastic $(25.2 \%)$, followed by paper $(22.7 \%)$, glass $(2.6 \%)$, ferrous $(2.1 \%)$, textiles

\footnotetext{
${ }^{\text {a }}$ Corresponding author : aeslina@uthm.edu.my
} 
$(0.9 \%)$ and lastly $1.8 \%$ for others [6]. Therefore, a continuous effort is required to identify the most suitable alternative for long terms solutions to reduce the burden of existing MSW disposal systems such as open dumping and landfilling specially on food waste.

The issues of food waste that represent the highest percentage in MSW component are now starting to become a regional issue even for developed countries, thus alternative method is in need. For countries such as Korea and Japan, they practice the separation of food waste from other solid waste because of the biodegradability of the food waste, lack of landfill space as well as transport and disposal of food waste problem that occurs in many combustion processes [7].

Food waste is one of the important components of MSW generated and the disposal in landfills has critical environmental effects [8]. Furthermore, a constantly increasing population makes the land available to use as landfills is more difficult to find and local governments are facing with the need to extend the life of their landfills and avoid the cost of developing a new landfill.

In Malaysia, the solution to solve the problem of solid waste management based on the concept of environmentally acceptable to the public is in need. The commingled in Malaysia without any separation need to be resolved immediately because food waste accounts for almost $45 \%$ of municipal solid waste. Total generation of food waste is a major cause of many problems associated with the landfill, such as odor, toxic leachate, and greenhouse gas emissions [9].

Food waste recycling in Malaysia is rarely implemented. There are several options for implementing the method of recycling food waste such as composting, anaerobic digestion or biogass technology and recycling of yellow grease. Few numbers of countries have implemented the recycling method including Germany and Britain [10] that perform the anaerobic decomposition by nurturing methane gas to be used as fuel. Countries like Japan, China, Indonesia and Philippines are known for using backyard composting and successfully reduce their food waste produced.

\section{Composting}

Composting is a natural recycling system that breaks organic matter down into valuable nutrition to the soils. The benefit of composting is that it can reform soil structure, texture and aeration and improve the capacity of the soil to hold water. Furthermore, utilizing composting as a fertilizer could develops good root formation in soil. Composting also has the ability to improve soil conditions and can contribute to the reduction of greenhouse gas emission and groundwater pollution as well as reducing the total amount of waste [11].

There are many types of composting and each method has different features. Generally, there are two major types of composting namely anaerobic and aerobic. The first method is processed in the absence of oxygen and the second one is processed in the presence of oxygen. Anaerobic composting is less labour intensive as it does not require frequent turning of the pile. It is a low-temperature process because the process of decomposition by anaerobic bacteria requires less energy released [12]. However, unlike aerobic composting, anaerobic compost maintains both seeds of weeds and pathogenic microorganisms because the temperature produced is not high enough to kill them. Hence, it is more unsanitary and there might be higher incidence of serious diseases occurred. Moreover, anaerobic composting decomposes at a very slow rate and produces a strong odour.

Conversely, aerobic composting is a high-temperature process because the process of oxidizing compounds requires more energy. However, the temperature will decrease gradually after intense activity of microorganisms. Therefore, occasional monitoring of moisture and temperature are needed to maintain air circulation during this process. Therefore, it will need more labours to mix the pile thoroughly. However, the process of decomposing is faster than anaerobic methods and there is less unpleasant odour [13]. People usually show their resistance towards home composting due to the particular smell or the presence of flies [14]. Hence, aerobic composting may achieve higher public acceptance by local people. Composting method continues to attract more users not only due to being an environmentally sustainable product but also for its great qualities as soil amendment. Compost utilization will assist to improve soil quality and reduces soil loss, and also increases soil water retention and reduce the need for extra inputs [15]. 


\section{Overview of Composting Based on Variable Feedstock Material}

Composting is the best process to reduce the amount of waste in landfill, since up to $30 \%$ of the materials send to the landfill is organic and could be composted. Compost application returns nutrients to the land, hold moisture in gardens and on lawns, contributes to watershed health by controlling runoff and naturally fertilize and provide structure to the soil. There are many types of animals and agricultural waste that can be used on compost making. It is essential to mix carbon-rich materials such as dried leaves, woody materials and straw with nitrogen-rich materials such as grass, fresh plant cuttings and manure because different types of organic matter contain different proportions of carbon (C) and nitrogen $(\mathrm{N}) . \mathrm{C} / \mathrm{N}$ ratio for compost should be maintain at $25-50$ because if the $\mathrm{C} / \mathrm{N}$ ratio is in lower ratios, ammonia is given off and biological activity is also impeded at lower ratios. On the other hands, at higher ratios nitrogen may be a limiting nutrient. This review will consist of two main feedstock materials which are animal waste and agricultural waste.

\subsection{Animal waste}

Compost made from animal waste and other organic refuse can serve as a valuable nutrient resource to the agricultural fields, and decrease environmental load if they are treated properly. Frank et al. [16] used cow dung and poultry litter along with banana peels in their study. Poultry litter and cow dung are wastes that may fit in the category of nitrogen supplements (low $\mathrm{C} / \mathrm{N}$ ratio $<12$ ). The characteristics of cow dung shows that $\mathrm{pH}$ value with 6.6, electrical conductivity (EC) with $11.1 \mathrm{dS}$ $\mathrm{m}-1, \mathrm{C} / \mathrm{N}$ ratio with 13.4 , phosphorus $(\mathrm{P})$ value with $2.41 \mathrm{~g} / \mathrm{kg}$ and potassium $(\mathrm{K})$ value with 38.61 $\mathrm{g} / \mathrm{kg}$. On the other hand, the characteristics of poultry litter is different with $\mathrm{pH}$ value of 7.7 , EC value with $10.01 \mathrm{dS}$ m-1, C/N ratio with 7.6, P value with $14.8 \mathrm{~g} / \mathrm{kg}$ and $\mathrm{K}$ value with $17.62 \mathrm{~g} / \mathrm{kg}$. The C/N ratio of the cow dung and poultry litter itself is in low ratio which is good to help the compost in the maturity process. The result of the compost with cow dung and banana peels started with $\mathrm{C} / \mathrm{N}$ ratio of 15.5 and after 12 weeks the value drop to 10.5 . While the $\mathrm{C} / \mathrm{N}$ ratio value for compost with poultry litter and banana peels is start with 14.6 and becoming 10.2 after 12 weeks. The final compost $\mathrm{C} / \mathrm{N}$ ratio of the compost was within the range of 10-15, which is ideal for final stabilized composts [17].

Cow manure also have been used by Nonglak et al. [18] along with urea fertilizer, tobacco plant waste and compost inoculum in their study. The cow manure were air dried at $80^{\circ} \mathrm{C}$ for 24 hours and pressed trough a $0.2 \mathrm{~mm}$ sieve. The result shows that the highest temperature of the compost is $62^{\circ} \mathrm{C}$, $\mathrm{pH}$ value with 11.78 to 7.78 and initial value of $\mathrm{C} / \mathrm{N}$ ratio with 17.76 and then decreased to 12.27 at day $50 . \mathrm{C} / \mathrm{N}$ ratio in this study also cannot be used as an absolute indicator of compost maturation same as Frank et al. [16] study since the initial C/N ratio was below 20. However, the compost in this study is apparently reached maturity faster within 30 to 40 days as also indicated by the decreased of temperature. Cow manure can be concluded as a good feedstock material as it help to speed up the maturity process of compost.

Swine manure can be an excellent source of nutrients for crop production and to be known as an economical fertilizer. Jishao et al. [19] used fresh swine manure as the raw materials along with wheat straw at a ratio of 10.5: 1 in aerated static composting box with dimension $0.65 \mathrm{~m} \mathrm{x} 0.50 \mathrm{~m} \times 0.40 \mathrm{~m}$. The moisture content of the swine manure is $70.9 \%$ with $\mathrm{C} / \mathrm{N}$ values of 12.8 . The result shows that the initial value of the compost with $\mathrm{pH}$ value of $6.5, \mathrm{EC}$ value with 3.5 and $\mathrm{C} / \mathrm{N}$ ratio with 12.9 . The maximum temperature in the compost was $65.2^{\circ} \mathrm{C}$ at day 8 . The final value of the compost is $\mathrm{pH}$ with 8.9, EC value with $2.2 \mathrm{~ms} . \mathrm{cm}-1$ and $\mathrm{C} / \mathrm{N}$ ratio with 9.4. In this study, $\mathrm{C} / \mathrm{N}$ could not be as an indicator because of the low initial $\mathrm{C} / \mathrm{N}$ (10-13), so the ratio of the ending value of $\mathrm{C} / \mathrm{N}$ to the initial $\mathrm{C} / \mathrm{N}$ (T) was used to estimate the maturity. The compost reached maturity when $\mathrm{T}$ value was ranged from 0.53 to 0.72 [20]. The value of $\mathrm{T}$ in this study is 0.73 which is almost reached the requirement of maturity. So, the study period should be longer to let the compost achieve the requirement of maturity. Therefore, swine manure is still a good feedstock material as it help the maturity process but it need a bit more time to achieve it. 
Chicken manure is also full of nutrients that will benefit the gardening plot. It has been used by Naser et al. [21] as one of the feedstock for their co-composting study along with sawdust. The EC of chicken manure is $7.49 \mathrm{ds} \mathrm{m}-1$ and the $\mathrm{pH}$ value is 7.99 . The characteristics of the chicken manure shows that the $\mathrm{C}$ value is $33.04 \%, \mathrm{~N}$ value is $3.73 \%, \mathrm{P}$ value is $2.02 \%$ and $\mathrm{K}$ value is $2.69 \%$. The result shows that the $\mathrm{C} / \mathrm{N}$ ratio started with 24 and ended with 34 . The $\mathrm{C} / \mathrm{N}$ values were high which is higher than the optimum value of 21 for matured compost. This is due to the high amount of recalcitrant carbon present in the feedstock mixture. Thus, chicken manure is not a good help for compost to achieve the maturity by depending on the $\mathrm{C} / \mathrm{N}$ value

\subsection{Agricultural waste}

In general, most of agricultural waste such as crop residues, sawdust, rice straw and others contain large amounts of carbon but low amounts of nitrogen and will cause slower decomposes process. So the organic material of the compost needs to contain the correct proportions of carbon and nitrogen. This is because the microorganisms that decompose the organic matter need both carbon and nitrogen to function well.

Many of previous researchers used sawdust as one of the material in their study. Sawdust is the most widely used bulking agent in the composting systems. Ying et al. [22] used sawdust along with food waste in their study at 1:1 ratio and the characteristics shows that the moisture content of the sawdust is $7.24 \%$, the TOC value is $52.9 \%$, the TKN value is $0.59 \%$ and the $\mathrm{C} / \mathrm{N}$ ratio is at 89.8 respectively. The result shows that the $\mathrm{pH}$ reached 8.0 after 21 days then was stable during the rest of the composting process. As for $\mathrm{C} / \mathrm{N}$ ratio the value decreasing from 25.5 to 18.1 after 56 days. The reduction of total carbon content but an increase in total nitrogen content resulted in a decrease of $\mathrm{C} / \mathrm{N}$ ratio indicating that the composts were becoming more stable and mature. $\mathrm{C} / \mathrm{N}$ ratio less than or equal to 20 is to be considered as satisfactory level for compost maturity [23], which is prove that sawdust is a good feedstock material if the mixture used is suitable.

Jiachao et al. [24] used rice straw which is difficult to be decomposed along with bran, soil and vegetables at ratio of 11:2:8:3. The rice straw was air-dried and cut into 10 to $20 \mathrm{~mm}$ lengths. The characteristics for rice straw are determined. The moisture content is $11.73 \%$, TOC value is $428.0 \mathrm{~g}$ $\mathrm{kg}-1, \mathrm{TN}$ value is $8.8 \mathrm{~g} \mathrm{~kg}-1$ and $\mathrm{C} / \mathrm{N}$ ratio is 48.8 accordingly. As for bran, the characteristics are $14.06 \%$ for moisture content, TOC value with $474.1 \mathrm{~g} / \mathrm{kg}$, TN value with $41.2 \mathrm{~g} / \mathrm{kg}$ and $\mathrm{C} / \mathrm{N}$ ratio with 11.5 respectively. The result shows that the temperature of the pile compost increased significantly to $56^{\circ} \mathrm{C}$ at the first 4 days and decreased gradually to the ambient level after a few days. On the other hand, $\mathrm{C} / \mathrm{N}$ ratio value decreased from 31.15 to 16.62 due to the decomposition of the organic matter by the microorganisms during the composting process and reached the maturity level of the compost. Thus, rice straw is a good feedstock material as the compost final result achieve the maturity level at satisfactory time.

In another research, bagasse, pine chip and banana waste was used by Brito et al. [25] as the materials for their composting at a ratio of 5:2.5:2.5. The characteristics for baggase indicates that the $\mathrm{pH}$ value is 4.9 , EC value with $4.72 \mathrm{dS} \mathrm{m}-1$, organic matter $(\mathrm{OM})$ with $81.5 \%$, TOC value with $40.4 \%$ and $\mathrm{N}$ value with $3.4 \%$. As for banana waste the $\mathrm{pH}$ value is 5.5 , EC value is $1.34 \mathrm{dS} \mathrm{m}-1$, OM value is $42.1 \%$, TOC with $1.63 \%$ and $\mathrm{N}$ value is $1.63 \%$. Meanwhile, the characteristics for pine chip is $\mathrm{pH}$ with 5.3, EC value with $0.20 \mathrm{dS}$ m-1, OM value with $86.6 \%$, TOC value with $53.9 \%$ and TN $0.28 \%$. The result shows that the $\mathrm{pH}$ value is around 4.7 to 6.7 , the TN value increased from $2.36 \%$ to $4.07 \%$ and the $\mathrm{C} / \mathrm{N}$ ratio also decreasing from the beginning of the process until day 126 with the value of 9.6 which is showed an acceptable degree of maturation [26]. Therefore, the mixture of bagasse, pine chip and banana waste as feedstock material in composting is also proven to be good.

\section{Conclusions}

Based on the literature review, we can see that the selection of the feedstock materials is based on the characteristics of the material itself. The selection of the organic material can be any type of plants or 
animals with suitable proportions of $\mathrm{C}$ and $\mathrm{N}$. The microorganisms decompose the organic matter need both carbon and nitrogen to function well. Nitrogen-rich material such as fruit, vegetables peels and young leaves that expedite decomposes process that contains low levels of carbon but high levels of nitrogen. Carbon-rich material such as crop residues and small twigs that decomposes slowly contains large amounts of carbon but low amounts of nitrogen. Too little nitrogen in material means the composting process will be slow, too much of it will result in the material becoming acid and smelly. The ideal ratio of carbon and nitrogen for starting a compost pile is 25-50: 1 . Therefore, the selection and combination of feedstock materials is important for the quality of compost. Most of the previous study successfully reached the standard of maturity with the compost feedstock material their chosen.

\section{References}

[1] P. Agamuthu and S.H. Fauziah, MSW disposal in Malaysia: Landfill management, Proc. of the 2nd Expert Meeting on Solid Waste Management in Asia and the Pacific Islands, Kitakyushu, (2006).

[2] P. Agamuthu, K.M. Khidzir and F.S. Hamid, Drivers of sustainable waste management in Asia, Waste Management and Research, 27, 625-633, (2009).

[3] P. Agamuthu and S.H. Fauziah, Sustainable management of wet market waste, Proc. of the Int. Conf. on Sustainable Solid Waste Management, 239-243, (2007).

[4] S.H. Fauziah, Municipal Solid Waste Management: A Comprehensive Study in Selangor, PhD Thesis, University of Malaya, Kuala Lumpur, (2009).

[5] C. Visvanathan, O. Tubtimthai and P. Kuruparan, Influence of landfill top cover design on methane oxidation: Pilot scale lysimeter experiments under tropical conditions, Proc. of the 3rd Asia Pasific Landfill Symposium, Kitakyushu, (2004).

[6] K.H. Chua, E.J.M. Sahid and Y.P. Leong, Sustainable Municipal Solid Waste Management and GHG Abatement in Malaysia, ST-4: Green and Energy Management, 1-8, (2011).

[7] M.H. Kim and J.W. Kim, Comparison through a LCA evaluation analysis of food waste disposal options from the perspective of global warming and resource recovery, Science of the Total Environment, 408 (19), 3998-4006, (2010).

[8] Environmental Protection Agency, Basic Information about Food Waste, (2009) < retrieved from http://www.epa.gov/osw/conserve/materials/organics/food/fd-basic.htm>

[9] S.H. Lee, K.I. Choi, M. Osako and J.I. Dong, Evaluation of environmental burdens caused by changes of food waste management systems in Seoul, Korea, Science of the Total Environment, 1(3), $42-53$ (2007).

[10] A.D. Knipe, The management of household food waste, Environmental Research and Consultancy, West Morden, United Kingdom, (2005).

[11]C. Muller, Decentralised composting in developing countries: Financial and technical evaluation in the case of Asmara City, Diploma Thesis of Christian Müller, Swiss Federal Institute of Technology, Zurich, (2005).

[12]D. Gaschk, T. Ayaka, V. Hanh, Dominique Wisniewski, Waste Management in Devikulam. Sustainability in Developing Communities, (2009)

[13]C. Henry, Chapter VII: Composting, (2005). <retrieved from http://www.unep.or.jp/ietc/ publications/spc/solid_waste_management/Vol_I/14Chapter.pdf $>$

[14]M. Ali, Sustainable composting: Case studies and guidelines for developing countries, Water, Engineering and Development Centre, Loughborough University, Leicestershire, (2004).

[15] United States Composting Council, Greenhouse gases and the role of composting: A primer for compost producers, (2008). <retrieved from http://www.compostingcouncil.org >

[16]K. Frank,N. Eiji, E. Tsuneyoshi, A. Zahoor, Y. Rumana, M.T. Moses and Y. Sadahiro, An evaluation of aerobic and anaerobic composting of banana peels treated with different inoculums for soil nutrient replenishment, Bioresource Technology, 126, 375-382, (2012). 
[17]A. Boldrin, I. Korner, U. Krogman and T.H. Cristensen, Composting:mass balances and product quality, Solid Waste Management, 978, 1-3, (2010).

[18] S. Nonglak, D. Srisulak, S. Panalak, J. Somsak, B. Sukanya, W. Janewit and J. Chaiwat, Composting of tobacco plant waste by manual turning and forced aeration system, Maejo Int. J. Sci. Technol., 3(02),248-260, (2009).

[19] J. Jishao, H. Yimei, L. Xueling and H. Hua, The effects of apple pomace, bentonite and calcium superphosphate on swine manure aerobic composting, Waste Management, 34, 1595-1602, (2014).

[20]M. Itavaara, M. Vikman and O. Venelampi, Windrow composting of biodegradable packaging materials, Compos. Sci. Utiliz., 5, 84-92, (1997).

[21] K. Naser, C. Ian, A.S. Miguel, S. Syd, M. Sebastian and B. Nanthi, Maturity indices in cocomposting of chicken manure and sawdust with biochar, Bioresource Technology, 168, 245-251, (2014).

[22]Z. Ying, S. Ammaiyappan and W.C.W. Jonathan, Evalution of humic substances during cocomposting of food waste, sawdust and chinese medicinal herbal residues, Bioresource Technology, 168, 229-234, (2014).

[23] M.F. Hirai, V. Chanyasak and H. Kubota, A standard method for measurement of compost maturity, Biocycle, 24, 54-56, (1983).

[24]Z. Jiachao, Z. Guangming, C. Yaoning, Y. Man, Y. Zhen, L. Hui, Y. Yong and H. Hongli, Effects of physico-chemical parameters on the bacterial and fungal communities during agricultural waste composting, Bioresource Technology, 102, 2950-2956, (2011).

[25]E. Brito, M.A. Bustamante, C. Paredes, J. Moreno-Caselles, M.D. Perez-Murcia, A. PerezEspinosa and R. Moral, Composting of brewery wastes with agricultural and forest residues. <retrieved from http://www.ramiran.net/ramiran2010/docs/Ramiran2010_0114_final.pdf $>$

[26]M.P. Bernal, C. Paredes, M.A. Sanchez- Monedero and J. Cegarra, Maturity and stability parameters of compost prepared with a wide range of organic waste, Bioresource Technol., 63, 91-99, (1998). 